\title{
Herpes zoster internuclear ophthalmoplegia
}

\author{
Vijayashankar Paramanandam, Sowmini Perumal, Malcolm Jeyaraj, Sakthi Velayutham, Gobinathan Shankar \\ Department of Neurology, Stanley Medical College \& Hospital, Chennai 600001, Tamilnadu, India.
}

\section{$A$ B S T R A C I}

Internuclear ophthalmoplegia (INO) is caused by a lesion in the medial longitudinal fasciculus. Patients with INO are usually asymptomatic but may have diplopia and oscillopsia. The most common causes of INO are ischemia and demyelination. Occurrence of INO due to infectious etiologies like tuberculosis, AIDS, brucellosis, cysticercosis and syphilis is well known. However, clinical presentation of INO associated with herpes zoster is very rare. The possible pathogenic mechanism for varicella zoster virus (VZV) induced INO could be demyelination or microinfarction in the brainstem. In the present study, a case of 56 years old male with double vision, with a recent history of herpes zoster, has been reported. Clinical examination revealed right INO. VZV IgM antibodies were positive and patient recovered fully after treatment with acyclovir and steroids.

Key words: Demyelination; herpes zoster virus; internuclear ophthalmoplegia; medial longitudinal fasciculus; varicella zoster virus

\section{INTRODUCTION}

In Internuclear ophthalmoplegia (INO) there is damage to the medial longitudinal fasciculus (MLF) between the 3rd and 6th cranial nerve nuclei which impairs the transmission of neural impulses to the ipsilateral medial rectus muscle. ${ }^{[1]}$ It is clinically characterized by failure to adduct the ipsilateral medial rectus and nystagmus of the abducting eye. Tuberculosis, brucellosis, cysticercosis, syphilis and multiple sclerosis are the common infectious diseases which are responsible to cause INO in a patient. ${ }^{[2]}$ Herpes zoster is a relatively rare etiology of INO. To the best of our knowledge, only two studies focusing on the association between herpes zoster and INO have been published so far. In agreement to the previous publications; we report here the case of a patient with INO, who also had herpes zoster vasculopathy. The goal of this report is to highlight the rare case of herpes zoster leading to INO.

\section{CASE REPORT}

A 56 years old male presented with diplopia in the left

Corresponding Author: Dr. Vijayashankar Paramanandam, Department of Neurology, Stanley Medical College, Old jail road, Chennai 600001, Tamilnadu, India.

E-mail: drvijayashankar@gmail.com

\begin{tabular}{|l|l|}
\hline \multicolumn{2}{|c|}{ Access this article online } \\
\hline Quick Response Code: & Website: \\
\hline & http://nnjournal.net \\
\cline { 2 - 2 } & \\
\hline
\end{tabular}

gaze was admitted. The diplopia worsened while looking at the distant objects. Occular examination revealed that he had right INO showing restriction of adduction in the right eye with nystagmus on abduction in the left eye. His vertical eye movements and convergence were normal. Pupil and fundus examination were normal. Rest of the neurological examination was also normal. Neck stiffness was not present. He had no fever. Healed herpetic scars were present in the left maxillary region.

Two weeks before the onset of diplopia he was diagnosed with herpes zoster and was under treatment with oral acyclovir. He did not have any other co-morbid illness. A previous history of chicken pox infection at the age of 10 years was reported.

Routine blood examination including complete blood count, renal function test and electrolytes were normal. Chest $\mathrm{x}$-ray and electrocardiogram were also normal. Magnetic resonance images (MRI) scans of the brain with contrast revealed no abnormality. Cerebro-spinal fluid analysis showed pleocytosis and elevated protein with normal sugar level. Serum Varicella zoster IgM antibody was positive.

The patient was treated with intravenous (IV) acyclovir

This is an open access article distributed under the terms of the Creative Commons Attribution-NonCommercial-ShareAlike 3.0 License, which allows others to remix, tweak, and build upon the work non-commercially, as long as the author is credited and the new creations are licensed under the identical terms.

For reprints contact: service@oaepublish.com

How to cite this article: Paramanandam V, Perumal S, Jeyaraj M Velayutham S, Shankar G. Herpes zoster internuclear ophthalmoplegia. Neuroimmunol Neuroinflammation 2016;3:102-3.

Received: 29-09-2015; Accepted: 20-12-2015 
and IV methylprednisolone followed by oral prednisolone. He symptomatically improved within two months.

\section{DISCUSSION}

In this study, the patient had right INO with a recent history of herpes zoster infection presenting painful rash distribution along V3 branch of the left trigeminal nerve. He possibly had damaged right MLF, without exhibiting significant brainstem lesions in the MRI of the brain. The positive serum herpes zoster IgM antibody report of the patient suggested recent reactivation of the latent VZV. The exact pathogenic mechanism by which Varicella zoster causes INO has not been elucidated, however, some studies assume it is due to multifactorial etiologies. The proposed hypothesis are: demyelination in the brainstem; ${ }^{[3]}$ microinfaractions in the brainstem due to inflammatory meningovasculitis producing small vessel vasculopathy of the supplying cranial nerves. ${ }^{[4]}$

The herpes zoster particles spread along trigeminal afferent fibers and cause small vessel vasculopathy. Initially the reactivated virus spreads transaxonally to the arterial adventia and then spreads transmurally to the lumen. It causes thickening of intima, disruption of elastic lamina and loss of smooth muscle cells, which leads to occlusion of the involved vessel. ${ }^{[4]}$ It has been found to be associated with disruption of atheromatous plaque and hypercoagulability induced by VZV. ${ }^{[5]}$ It has also been shown that the herpes zoster vasculitis may closely mimic Giant cell arteritis (GCA). ${ }^{[6]}$ Till date, only two studies have reported cases of herpes zoster infection induced INO. Caroll et al. ${ }^{[3]}$ suggested that the pathologic process was due to the onset of demyelinating process in the brainstem, whereas, Al-Abdulla et al. ${ }^{[7]}$ reported it could be due to herpes zoster vasculopathy that can mimic GCA. The authors reported MRI of the brain of the patient was normal; which was observed in this study as well.

Varicella zoster vasculopathy after primary infection or reactivation may involve large vessels causing unifocal granulomatous arteritis and small vessels causing multifocal vasculopathy. ${ }^{[8]}$ Histopathological studies on arteries with Varicella zoster vasculopathy shows VZV DNA, VZV antigen, herpes virus particles, Cowdry A inclusions and multinucleated giant cells. ${ }^{[9]}$

In our present study, although the patient had a definite clinical history of recent herpes zoster supported by positive serum VZV IgM antibody, the MRI of the brain with magnetic resonance angiography was found normal. It is possible that microinfarctions due to restriction of the disease inflammation to a small single artery in the brainstem were not detected in MRI scans of the brain.

A spectrum of neurologic complications may follow herpes zoster infection such as motor neuropathies of the cranial and peripheral nervous system, encephalitis, meningoencephalitis, myelitis and Guillain-Barre syndrome. Our patient had presented INO after herpes zoster infection, which is a very rare neurological manifestation of VZV, however, he recovered completely with appropriate treatment. We wanted to highlight this case because of its infrequency of occurrence.

\section{Financial support and sponsorship}

Nil.

\section{Conflicts of interest}

There are no conflicts of interest.

\section{REFERENCES}

1. Bae YJ, Kim JH, Choi BS, Jung C, Kim E. Brainstem pathways for horizontal eye movement: pathologic correlation with MR imaging. Radiographics 2013;33:47-59.

2. Lavin PJM. Neuro-ophthalmology: oculo motor system. 6th ed. Daroff RB, Fenichel GB, Jankovic J, Mazziotta JC, editors. Bradley's neurology in clinical practice. Philadelphia: Elsevier; 2012.

3. Caroll WM, Mastaglia FL. Optic neuropathy and ophthalmoplegia in herpes zoster oticus. Neurology 1979;29:726-9.

4. Gilden D, Nagel MA, Cohrs RJ, Mahalingam R. The variegate neurological manifestations of varicella zoster virus infection. Curr Neurol Neurosci Rep 2013;13:374

5. Langan SM, Minassian C, Smeeth L, Thomas SL. Risk of stroke following herpes zoster: a self-controlled case-series study. Clin Infect Dis 2014;58:1497-503.

6. Nagel MA, Gilden D. Update on varicella zoster virus vasculopathy. Curr Infect Dis Rep 2014;16:407.

7. Al-Abdulla NA, Rismondo V, Minkowski JS, Miller NR. Herpes zoster vasculitis presenting as giant cell arteritis with bilateral internuclear ophthalmoplegia. Am J Ophthalmol 2002;134:912-4.

8. Chiang F, Panyaping T, Tedesqui G, Sossa D, Costa LC, Castillo M. Varicella zoster CNS vascular complications. A report of four cases and literature review. Neuroradiol J 2014;27:327-33.

9. Nagel MA, Gilden D. Varicella zoster complications. Curr Treat Options Neurol 2013;15:439-53. 